\title{
The Current Situation, Problems, and Suggestions of Film and Television Education in Primary and Middle Schools
}

\author{
LI Ying, GUO Yu-zhen \\ Liaocheng University, Liaocheng, China
}

\begin{abstract}
This study investigates the current situation of the film and television education in primary and secondary schools in China. The purpose is to find out the problems existing in the current film and television education in primary and secondary schools, and give improvement measures. A questionnaire was designed in this study and teachers in 89 primary and secondary schools in Liaocheng City, Shandong Province filled in the questionnaires. A total of 355 valid questionnaires were collected. This study analyzed the survey data, and drawn a series of conclusions about the current situation of film and television education in primary and secondary schools on the basis of data analysis. Based on the results of the survey, some suggestions are given to provide reference for the development of film and television education in primary and secondary schools.
\end{abstract}

Keywords: film and television education, current situation, survey, curriculum system

In recent years, China witnesses a vigorous development of film and television industry. As digital natives, watching videos through the internet has become an integral part of teenagers' lives. However, videos on the internet are intermingled. The teenagers are easily influenced by the wrong values instilled by some internet videos, such as worshiping internet celebrities and movie stars blindly. To solve this problem, there's an urgent need for developing film and television education and enhancing the artistic appreciation of teenagers.

In December 2018, The Ministry of Education of China and the Publicity Department of Central Committee of the Chinese Communist Party jointly issued Guiding Opinions on Strengthening Film and Television Education in Primary and Secondary Schools (The Ministry of Education of China, 2018) (Hereinafter referred to as Guiding Opinions). The Guiding Opinions clearly pointed out the significance and missions of film and television education in primary and secondary schools. It presented that film and television education should be universalized in primary and secondary schools across the country in 3-5 years. The publication of the Guiding Opinions has aroused great repercussions in the educational circles and got enthusiastic response from film and television educators. How to realize the value of film and television education better in primary and secondary schools has become an important issue for educators. What is the current situation of film and television education in primary and secondary schools? What are the views of teachers and parents on film and television education? What's the implementation environment of film and television education and what is the current level of film and television education teachers in local primary and 
secondary schools? What is the demand for film and television resources in primary and secondary school? What problems exist in current film and television education in primary and secondary schools? The answer is urgently needed by the national and local education authorities and the film and television producers.

\section{Method}

This study investigates the current situation of film and television education in primary and secondary schools in Liaocheng City, Shandong Province. The study was mainly conducted by surveying the primary and secondary school teachers by questionnaire, complemented with informal interviews with teachers and parents.

\section{Design of Questionnaire}

The frame of the questionnaire was constructed by the main tasks of the film and television education in primary and secondary schools proposed by the Guiding Opinions. The questionnaire included the instructions, the basic information of schools and teachers, and questions about the current situation of film and television education. The instructions explained the purpose of the questionnaire survey. The basic information included the names of schools, the nature of the schools, the schools' location, the teachers' teaching grades, and the information of their curriculums. A total of 20 questions were devised about the current situation of film and television education. These 20 questions covered five aspects, including education plans, film resources, the conditions and channels of watching films, film and television education activities, and the teaching staff. Questions in the questionnaire expanded from two levels: schools and individual teachers. We want to know not only the present situation of film and television education in schools, but also the personal attitude of teachers towards film and television education. Therefore, this study involves two analysis units: the schools and the individual teachers.

\section{Sampling Design and Implementation}

The survey was conducted in June 2019. Questionnaires are distributed to primary and secondary teachers through the questionnaire star platform. A total of 363 questionnaires were collected, among which 355 questionnaires are valid. The valid questionnaires were analyzed by SPSS. The distribution of questionnaires covers all counties and districts of Liaocheng City. Teachers participated in the investigation come from 89 schools, among which 83 are public schools and six are private schools. There are 50 urban schools, 31 township schools, and eight rural schools. There are 35 primary schools, 30 junior high schools, and 24 senior high schools. The sample is quite representative in Liaocheng.

\section{Findings and Discussion}

\section{Survey Results Taking the Schools as the Analysis Unit}

The impact of sample homogenization should be fully considered when taking the school as the analysis unit. First, when analyzing the answers of the school level questions from the different teachers in the same school, a high degree of consistency was found. After removing the inconsistent samples, 89 samples from 89 schools were selected for analysis. The survey results are analyzed from five dimensions of the questionnaire.

Most schools have not put film and television education courses in their educational plans. Only 12 schools of all the 89 schools offered courses related to film and television education. In the schools which offered film and television education courses, three forms are used most: Comprehensive Practice (45.8\%), 
Lectures on Special Subjects (41.7\%), and Interest Group (45.8\%). 58.3\% of these schools offered film and television education courses less than four hours per semester. There were no evaluations for film and television education in all the schools.

The choice of films relies on teachers' personal experience. In schools that offered courses related to film and television education, most of the films were selected by teachers themselves (75\%), secondly from media introduction (25\%) and expert recommendation (25\%). This shows that at present the choice of film depends more on the teachers' personal experience. Few film and television experts are involved. The relevant media also did not play an adequate role in promoting and guiding of the selection of films.

The infrastructure for film and television education is moderate, while the channel to watch films is insufficient. The survey showed that $45.5 \%$ of schools have special film projection places, $79.2 \%$ have film projection equipment that can ensure the quality of projection, but $70.8 \%$ had never organized students to go to the cinema to watch movies. From the interviews we know that the daily management of primary and secondary schools is quite strict. Generally, the schools will not organize out of school activities except at some special festivals, due to the consideration of time and safety.

The film and television education activities are not rich enough. About the question of which of the following activities have been carried out in your school, $49.4 \%$ of the schools had never carried out any film and television education activity, $25.8 \%$ of the schools have organized drama play, $21.3 \%$ have launched film review competitions, and $11.8 \%$ have organized the students to perform in movies. No other option has the selection rate of more than $10 \%$. We found from the interview that in some schools many film and television works had been created by the Photography Club and the UAV Club. But the club activities rely more on the students' self-study, lacking the guidance from the teachers. The Student Development Centre of the school is responsible for such student clubs. However, its responsibility is limited in censorship and publicity of their works, failing to play an active guiding role for the students.

Status of teachers. In the schools offering the film and television courses, teachers who undertake the teaching of film and television education courses have other professional backgrounds. Among them the top two are information technology teachers (46\%) and Chinese teachers (21\%). Literature itself is inextricably linked with film and it is the natural choice of some schools to arrange Chinese teachers to undertake film and television education courses. It's to our surprise that information technology teachers get a high selection rate of $46 \%$. We found from the interviews that in many schools the information technology teachers also serve as electrified education teacher and they undertake the task of projecting films. Naturally, they became part-time teachers of film and television education. We also found from the interview that the teachers who undertake the teaching of film and television education courses have not participated in the training of film and television knowledge; they lack of deep understanding of professional theory and educational theory of film and television.

\section{Survey Results Taking the Individual Teachers as the Analysis Unit}

A total of 355 samples have been surveyed. The survey results were carried out in three aspects. They were teachers' teaching behavior related to film and television education, teachers' understandings of the values of film and television resources, teachers' film and television knowledge needs and other needs. 
Teachers' teaching behavior related to film and television education. The findings from the survey indicate that $83.1 \%$ of teachers have shown video clips in their class. The teachers mainly obtain film and television resources through the Internet (95.2\%), secondly from other people (26.8\%). Some teachers said that the resources on the internet are intermingled, and various problems could be encountered in the download procession. It had taken too much time.

About the question of "what kind of films the teacher will show to the students", biographical films got the highest selection rate (55.8\%), next are historical films (52.1\%), science and education films (49.6\%), and documentaries (37.7\%).

Understanding of the values of film and television resources. $97.5 \%$ of the teachers thought that film and television resources were helpful to subject teaching, $97.7 \%$ of the teachers thought that film and television resources could help students develop their Key Competencies, and $89.6 \%$ of the teachers thought it is necessary to set up the film and television education courses in primary and secondary schools. The survey results indicated that teachers had a positive understanding of the value of film and television resources.

Teachers' film and television knowledge needs and other needs. About the question of "what kind of film and television professional knowledge do you lack", the answers were presented below according to the selection rate from high to low: microfilm creation (76.6\%), basic theory of film and television (69.9\%), film and television frontier knowledge (59.4), film projection knowledge (46.8). To carry out film and television knowledge training for primary and secondary school teachers, the basic theory of film and television and the content of microfilm creation should be arranged preferentially.

About the question of "what are the main factors affecting the implementation of film and television education in primary and secondary schools", the answers were presented below according to the selection rate from high to low: lack of curriculum standards (75.8\%), lack of teachers (70.4\%), lack of teaching materials (67.9\%), lack of class hours (50.1\%), lack of national policy (47.9\%), school leaders do not attach importance to it (38\%).

\section{Suggestions}

\section{Having a Top-Level Design and Establishing Curriculum System}

Under the current system, it is needed to be guaranteed to have a place in the national curriculum to universalize film and television education in primary and secondary schools throughout the country, and this involves the top-level design. The top-level design is a comprehensive and forward-looking design of film and television education curriculum at the national level, which should formulate the fundamental direction of film and television education in primary and secondary schools. It should stipulate the curriculum objectives, class hours, teaching materials, teachers' allocation, and evaluations for film and television education courses. It should help to avoid the arbitrary, superficial and formalism tendencies in curriculum implementation and to avoid the tendency of excessive entertainment.

\section{Exploring the Effective Teaching and Evaluation Methods}

The characteristics of the film and television course determine that it needs special teaching and evaluation methods. Some schools have carried out meaningful exploration on the teaching methods of film and television courses. For example, Qianjin Primary School in Haidian District of Beijing had explored an integrative film 
and television education activity mode of watching, commenting, reading, writing, and performing (Wang, 2019, pp. 90-95). The implementation mode of film and television education should be diversified. The implementation mode may include: setting up independent film and television education courses, integrating film and television curriculum with subject curriculum, developing film and television education in thematic class meetings, carrying out essay solicitation activities and blackboard, handwritten paper design activities related to film and television, carrying out film and television creation practice activities such as organizing school film festivals, microfilm creation, creation of hometown image film, performing and dubbing, organizing students to visit the film archive, the film museum, the film studio, the film and television production and communication companies and other relevant places. What a mature film and television education requires is not a few scattered teaching methods; it requires a teaching method system that helps to realize the value of film and television education in primary and secondary schools. The exploration of teaching method system for film and television education needs the joint efforts of film and television experts, curriculum and teaching theory experts, and primary and secondary school teachers.

Evaluation is essentially an educational activity and it can help to maintain the sustainability of students' curriculum learning. The curriculum design of film and television education was more open. It does not emphasize the individual competition and sequence ranking about knowledge acquisition. It emphasizes the behavior and emotional changes of students in the process of learning. Knowledge and practice, morality and responsibility are all the core values of the film and television education. The traditional written test for the purpose of quantitatively examining the learner is not suitable for film and television education. The process evaluation should be the main form of evaluation of film and television education. The learning process of students should be recorded in the form of recording table and electronic portfolio. In this way, not only the changes of students' abilities can be discovered but also their internal psychological tendencies can be recorded, at the same time the students will be guided to participate in film and television education activities actively in long term.

\section{Training Film and Television Education Teachers in Different Ways}

First, full-time teachers' positions in film and television education should be established as far as possible. The full-time film and television education teachers should be held by the graduates majored in film and television. Secondly, film and television knowledge training should be provided for primary and secondary subject teachers. The training can be conducted through two channels: One is to provide face-to-face training by film and television department in colleges; the second is to develop online courses to provide training for primary and secondary school teachers. In addition, offering film and television courses for normal college students is also a way to improve the film and television literacy of future front-line teachers.

\section{Promoting the Construction of Film and Television Education Resource Database}

The construction of film and television education resource database can help to avoid the blindness of film selection. The classification of resource database should be as detailed as possible. The resource database should have different types of resources such as subject teaching resources, moral education resources, and resources for ideal and belief education. Resources should be divided according to different learning sections. When dividing, the students' physical and mental characteristics and cognitive rules should be studied in depth. 
For example, for junior students, we should pay attention to formative education and thanksgiving education. For middle stage students, the discipline education and anti-frustration education should be strengthened. The senior students are under great pressure; they should be inspired, be helped to release pressure, and be educated to be standardized in learning. In addition to meeting the needs of students to improve their film and television literacy and meeting their needs of cultivating integrity, video content that is integrated with the school education system should also be developed. These videos have strong academic nature; they help to meet the instruction oriented need of teachers and students. We should use scientific methods to carry out experiments to evaluate the educational effects of different kinds of films. In addition to the above, sometimes what the teachers need is not a whole film. What they need is a segment in the film that helps the students generate some kind of visual or emotional experience. Therefore, the editing, refinement, stratification, and classification of films are also an important work.

\section{Promoting the Whole Society's Understanding of Film and Television Education Through Various Ways of Publicity}

In interviews with parents of primary and secondary school students, they also expressed different views. Some parents said that the students' study burden was already very heavy, and children's school life was very stressful. They hope that no more courses should be added for students. Some parents also expressed that they support schools to show films with positive theme and films of learning to be a good person, but the normal study of students should not be affected. These views reflected the misunderstanding of some parents about film and television education in primary and secondary schools. It's a qualitative improvement more than an increase in quantity to develop film and television education in primary and secondary schools. It will not add the students' learning burden. It will make full use of the existing subject classes, the school-based courses, or other school activities to carry out film and television education guided by teachers on the basis of widely improving teachers' film and television literacy. The students will have lifelong benefit from the film and television courses. Parents' misunderstanding is not a problem in film and television education. Lack of publicity and failure to explain clearly the objectives and nature of film and television education were the cause of parents' misunderstanding. The orientation, nature, and implementation of film and television education in primary and secondary schools should be communicated to the society through various ways. By doing so, the implementation of the film and television education course may get the understanding of all sectors of society, especially parents of primary and secondary school students.

\section{References}

The Ministry of Education of China. (2018). Guiding opinions on strengthening film and television education in primary and secondary schools. The Ministry of Education of China. Retrieved from http://www.moe.gov.cn/srcsite/A06/s3325/201812/t20181224_364519.html

Wang, L. P. (2019). Ten years of perseverance, casting film and television education brand school: The practice of film and TV education in Qianjin Primary School, Haidian District, Beijing. Chinese Teachers, (4), 90-95. 